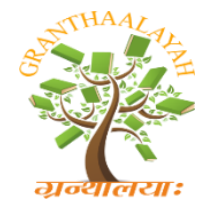

INTERNATIONAL JOURNAL OF RESEARCH GRANTHAALAYAH A knowledge Repository

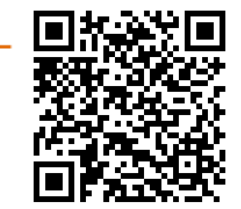

Management

\title{
REASONS WHY THE CUSTOMERS DISSOLVE THEIR BANKING RELATIONSHIP FROM EXISTING BANKS
}

\author{
Dr. S.N. Mahapatra *1, Parveen Kumar ${ }^{2}$ \\ ${ }^{*} 1,2$ Department of Management Studies, Deenbandhu Chhotu Ram University of Science \& \\ Technology, Murthal, Sonipat, Haryana, India
}

DOI: https://doi.org/10.29121/granthaalayah.v5.i6.2017.2025

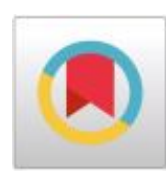

\begin{abstract}
The purpose of the study is to find out the reasons of customer relationship dissolution in banking industry. A structured questionnaire was distributed to banking customers based on demographics (gender, age, marital status, education, occupation and, income level) in National Capital Territory. Data was successfully collected from 500 respondents who have either saving account or current account or both. Respondents' opinion on 21 statements was obtained regarding their intension to dissolve their banking relationship with a particular bank. Principal Component Analysis with VERIMAX rotation on these 21 items was applied to extract the reasons behind dissolving banking relationship by customers. The study found that though there are various reasons why a customer dissolves its relationship with a particular bank but broadly these can be grouped into three categories includes Service Quality and Commitment; Price and Communication; and Involuntary Dissolution. Out of these three reasons, Service Quality and Commitment seems to be most important reason of dissolving a banking relationship.
\end{abstract}

Keywords: Relationship Dissolution; Banking Relationship; Service Quality; Price; Involuntary Dissolution.

Cite This Article: Dr. S.N. Mahapatra, and Parveen Kumar. (2017). "REASONS WHY THE CUSTOMERS DISSOLVE THEIR BANKING RELATIONSHIP FROM EXISTING BANKS." International Journal of Research - Granthaalayah, 5(6), 261-271. https://doi.org/10.5281/zenodo.820923.

\section{Introduction}

Banking system is considered as the backbone of every economy because economic development depends on the strength of banking system of that economy. Banking sector mobilises the financial savings and channelize these financial savings to productive use in the form of investment. In this way a vital role is being played by banking sector by mobilisation of financial savings and converting them into investment which in turn helps in achieving economic growth. There has been a remarkable transformation in the banking environment across the globe in past 
few decades. Certain structural, regulatory and technological changes have resulted into some significant changes in the banking industry competition level (Klein, 2005). Indian banking sector is also not left behind in this process of change which was started with the economic reforms of 1991 i.e. Liberalisation, Privatisation and Globalisation. The growing use of the internet banking and the smart phone banking based on $3 \mathrm{G}$ and $4 \mathrm{G}$ technologies will take user to the branchless banking in future. The technological developments in the banking industries have become the driving force where latest channels for delivering banking services are being used which increase the productivity and new customer acquisition. After the success of Automated Teller Machines (ATMs) and internet banking, use of mobile banking with the development of new application for smart phones has become the key instrument of banking services delivery. Due to continuous growth and change in above discussed factors banking environment has become dynamic throughout the world and same is witnessed in India as well. This dynamic environment provides certain opportunities to banker but they also bring some threats to banking industry. If any bank could not cope up with this dynamic environment it becomes very difficult to sustain the competition and it may create the risk of customer defection. Customer defection has an adverse impact on long term profitability. One other hand if long term relationship is maintained with customers then firms have to spend less money on marketing. According to Gronroos (1990), stated that "if close and long-term relationships can be achieved, the possibility is high that this will lead to continuing exchanges requiring lower marketing costs per customer".

According to Beckett et al. (2000) identical financial products/services offered by banks make customers more prone to change their banking preference. Losing a customer is a serious setback for the firms in respect to its present earning as well future (Sathish et al., 2011). Banking industry has become more subject to customer dissolution due to competition and homogenous products and services in banking industry (Chakravarty et al., 2004). Banking customers in India are having banking relationship with multiple service providers. This relationship with multiple service providers gives extra experience to customers and an extra (hidden) competition for service providers (Sajtos and Kreis, 2010), moreover market share and profitability is negatively affected by the defection of customers (Rust and Zahorik, 1993). It is because firms have to spend heavy on advertising, promotion, sales and on revealing customer needs; apart from it takes some time for new customers to become profitable (Athanassopoulos et al., 2001). Therefore it becomes inevitable for business organisations to know about the drivers of switching and have switching barriers and same is also applicable on banks. Various researchers have studied switching behaviour in respect to goods (McAlister and Pessemier, 1982; Kumar and Shashi, 1989) but there has been a little attention on switching behaviour of consumers in respect to services in financial sector (Friedman and Smith, 1993; Mittal and Lassar, 1998). Distinctive features of services like inseparability, intangibility, heterogeneity and perishability make the switching behaviour for services different from that of goods (Clemes et al., 2000). In today's competitive era most of customers have numerous banking service needs and majority of them have multiple banking service provider in order to obtain the best fees and rates. Various studies have revealed that the rate of attrition in Indian banking industry has accelerated in the recent years and their intention to switch their main bank has also increased. That is why to cope up with this changing environment Indian banks need to focus on establishing deeper bonds with their customers. It becomes necessary for the bank management to understand switching behaviour of their customers in order to influence their switching behaviour (Clemes et al., 2007; 
Beckett et al., 2000). Bank management can successfully dodge the ill effect of customer defection and build long-term relationship with its customers, if they clearly understand the factors affecting customers' switching behaviour (Clemes et al., 2007).

\section{Review of Literature}

It has been proposed that relationship must be seen as extended process covering affective, behavioural, cognitive and social aspects therefore it should not be seen as an event rather it should be seen as a process. Permanent breaking of relationship has been described as relationship dissolution. In a service industry it has been identified that the behaviour of service providers towards its customers is one of the main reason behind dissolution of any service provider-consumer relationship. Keaveney (1995) proposed that when customers encounter impolite behaviour from the service provider then they feel better to switch another service provider. Not only in service industry but in other industries as well staff behaviour is an important reason of dissolution of relationship. Halinen and Salmi (2001) argued that when customers felt that they are humiliated by supplier and their behaviour they end up with dissolution of relationship with that particular supplier which has a long lasting impact on supplier company's performance. Sometimes customers feel that their personal integrity is being compromised by the behaviour and attitude of service providers which force the customers to exit from the relationship with that service provider (Stewart, 1998). Gilliland and Bello (2002) suggest that loyal customers develop a sense of committed relationship with organisation which is based on psychological attachment with supplier. In such a situation customer would not break the relationship even though other competitor offers greater economic benefits. Some authors proposed that when a sales representative moves to another company customers may move with them, close and healthy relationship with the customers may be the cause behind such kind of dissolutions. On other hand it has also been identified that when task conflict between seller and buyer turns into relationship (emotional) conflict, then buyer starts hating the salesperson and mind of the customer cannot be changed at that particular point of time and it may cause dissolution of relationship (Reid et al., 2004). Bejou and Palmer (1998) described customer switching as permanent ending of relationship that is a result of dynamic process developed over a period of time. Customer switching has been defined as act of switching from one service provider to another due to dissatisfaction or any other reason by the customer (Keaveney and Parthasarathy, 2001; Sathish et al., 2011). Mahapatra (2014) stated that customer dissatisfaction needs to be addressed early and in proper manner. Dissatisfaction is mainly caused by firm's commitment towards customer care and customer expectations.

Previous studies have explained various reasons of customer dissolution in service industry in general and in banking industry in particular like customer satisfaction (Moutinho and Smith, 2000), Service Failure, Pricing and Inconvenience (Gerrard and Cunningham, 2004), Switching Cost (Maiyaki and Mokhtar, 2011), and ethical issues (Keaveney, 1995). Kura et al. (2012) examined the factors influencing customer switching and their relationship with customer switching. This study reveals that assurance and empathy has no significant relationship with customer switching. It has been found that assurance and empathy has significant positive relationship with word of mouth communication whereas word of mouth has significant negative relationship with customer switching. Levesque and McDougall (1996) investigated switching behaviour and complaining behaviour of banking customers, pricing issues and inconvenience of 
location were found to be important aspects causing customer switching in banking sector. Gerrard and Cunningham (2004) attempted to investigate the switching behaviour of Asian banking market and explained that service failure, pricing and inconvenience are important factors influencing switching behaviour of banking customers. It was also found that customer choose to switch the bank rather to discuss the underlying issues with bank staff because they feel that it would be a wastage of time to raise their voice. Mavri and Ioannou (2008) investigated the Greek banking customers' switching behaviour and found that product and service quality along with brand name has positive impact in reducing the switching tendency. Kaur et al. (2012) attempted to study switching intentions in Indian banking industry and found that service quality, satisfaction and trust have a significant impact on switching behaviour. Commitment of organisation is a binding force between service provider and customer which compels customers to continue its relationship with a particular service provider (Bansal et al., 2004). Friedman and Smith (1993) and Ganesh et al. (2000) proposed that among all the reasons of switching, involuntary switching was found main type of switching behaviour of customers in service industry. Stewart (1998) stated that dissatisfaction caused by one time service failure may not lead to dissolution of relationship, but repeated service failure promotes customers to exit from the relationship. Bolton (1998) established that in long term relationship service failure in not accepted by the customers. Service failure may force customer to break the long lasting relationship with the service provider. It was found from the literature review that there are various reasons behind relationship dissolution but mainly customers dissolve their relationship due to lack in service quality, commitment, reliability, involuntary dissolution behaviour of the staff and response to service failure etc.

\section{Research Objective}

A lot of research has been conducted on customer relationship dissolution/ customer switching since eighties. Many researchers tried to build the concept and find the reasons behind dissolving the relationship in both goods industry and service sector. Review of previous literature discloses that there are various reason behind dissolution of relationship in services sector like customer satisfaction (Moutinho and Smith, 2000), Service Failure, Pricing and Inconvenience (Gerrard and Cunningham, 2004), Switching Cost (Maiyaki and Mokhtar, 2011), and ethical issues (Keaveney, 1995) etc. In Indian banking sector an attempt was made by Vyas and Raitani (2013) to find out the drivers of customers' switching behaviour in Indian banking industry. This study undertakes to provide greater insight into consumers' intentions to dissolve their relationship with a particular bank, therefore objective of this study to inquire why consumers dissolve their relationship with a particular bank and to give suggestion for the maintenance of long term profitable relationship with the customer.

\section{Material and Methods}

In this paper emphasis is given to study why customers dissolve their relationship with a particular bank. After an exhaustive literature review it is decided to adopt descriptive research design for the study. To find out the reason behind relationship dissolution in banking industry an instrument was constructed. This questionnaire contains 21 statements related to relationship dissolution along with some questions on demographic profile of the respondents. Based on the above questionnaire a survey was conducted on 500 banking customer from National Capital 
Region. In order to qualify, respondents had to have at least one saving account or current account in any bank. The respondents were asked to rate the Reasons of Dissolving Relationship on Likert 5 point Scale from 'Strongly Disagree' to 'Strongly Agree' and weight 1 assigned to 'Strongly Disagree' and 5 to 'Strongly Agree'. 500 Questionnaire were distributed at the bank premises and were Face-to-Face administered in order to maximize the response rate and solve the queries of the respondents.

\section{Results and Discussion}

Descriptive research design was used to fulfill the objective of the study. Factor analysis was employed as data reduction technique and to find out the reasons of relationship dissolution in banking industry in India. The statistical package SPSS version 19 was used for data processing.

Table 1: Description of Demographic profile of the Respondents $(\mathrm{N}=500)$

\begin{tabular}{|l|l|l|}
\hline \multicolumn{1}{|c|}{ Characteristics } & Frequency & Percentage \\
\hline Gender & 302 & \\
Male & 198 & 60.40 \\
Female & & 39.60 \\
\hline Marital Status & 151 & \\
Single & 342 & 30.20 \\
Married & 7 & 68.40 \\
Separated & & 1.40 \\
\hline Age & 140 & \\
20-30 Years & 201 & 28.00 \\
30-40 Years & 92 & 40.20 \\
40-50 Years & 53 & 18.40 \\
50-60 Years & 14 & 10.60 \\
Above 60 Years & & 2.80 \\
\hline Academic Qualification & 6 & \\
Upto 8 & & 1.20 \\
10 & 10 & 2.00 \\
12 & & 5.80 \\
Diploma /Certificate & 29 & 13.00 \\
Graduation & 65 & 35.20 \\
Post Graduation & 176 & 23.80 \\
Professional Education & 119 & 19.00 \\
\hline Occupation & 95 & \\
Self Employed (Business-person) & 124 & 24.80 \\
Government Job/pensioner & 145 & 29.00 \\
Private Job & 164 & 32.80 \\
Practicing Professionals & 39 & 7.80 \\
Unemployed & 28 & 5.60 \\
\hline Income & 119 & 23.80 \\
Less than Rs.30000 & & \\
\hline
\end{tabular}


[Mahapatra et. al., Vol.5 (Iss.6): June, 2017]

ICV (Index Copernicus Value) 2015: 71.21
ISSN- 2350-0530(O), ISSN- 2394-3629(P)

IF: 4.321 (CosmosImpactFactor), 2.532 (I2OR) InfoBase Index IBI Factor 3.86

\begin{tabular}{|l|l|l|}
\hline Rs.30000 - Rs 80000 & 301 & 60.20 \\
Above Rs 80000 & 80 & 16.00 \\
\hline
\end{tabular}

Table 1 shows that out of total 500 respondents surveyed 302 are male i.e. 60.40 percent and remaining are the female respondents i.e. 198 constituting 39.60 percent of total respondents.

151 respondents are single, 342 are married and remaining 7 are separated, making 30.20 percent, 68.40 percent and 1.40 percent respectively. Majority of the respondents are below the age of 40 years as 40.20 percent and 28.00 percent respondents are in the age group of 20 years to 30 years and 30 years to 40 years respectively. There is less number of respondents above the age of 50 years as 10.6 percent and only 2.8 percent respondents are in the age group of 50 years to 60 years and above 60 years respectively. It can be inferred from the above table that middle aged people are engaged in the banking activities more actively as compared to younger and older generations. Out of total respondents 176 are graduates, 119 are post graduates and 95 are having professional qualification their respective percentages are 35.20 percent, 23.80 percent and 19.00 percent. The respondents with low level of education are showing least interest in the banking activities as only 9.00 percent respondents who have upto senior secondary qualification are least active in banking activities. Maximum of the respondents are private job holder, followed by government job holders/pensioner with the respective percentage of 32.80 percent and 29.00 percent. Practicing professionals are only 7.80 percent of the respondents which is less among all the occupations and 5.60 percent are unemployed. Middle income group respondents seem to have active participation in banking transactions as more than 60 percent respondents are having monthly income between Rs. 30000 to Rs. 80000 .

Table 2: Reasons of Dissolving Relationship

\begin{tabular}{|c|c|c|c|c|c|c|c|c|c|c|}
\hline \multirow{2}{*}{ Reasons } & \multicolumn{5}{|c|}{ Percentage } & \multirow{2}{*}{ Mean } & \multirow{2}{*}{ S.E.M } & \multirow{2}{*}{ S. D. } & \multirow{2}{*}{ Skew } & \multirow{2}{*}{$\begin{array}{l}\text { Cronbach's } \\
\text { Alpha }\end{array}$} \\
\hline & SD & $\mathbf{D}$ & $\mathbf{U}$ & $\mathbf{A}$ & $\mathbf{S A}$ & & & & & \\
\hline Increase in Fees/Penalties & 5.80 & 14.00 & 13.00 & 43.00 & 24.20 & 3.66 & 0.05 & 1.15 & -0.75 & 0.93 \\
\hline $\begin{array}{l}\text { Increase in Interest rate on } \\
\text { Loan }\end{array}$ & 5.40 & 9.20 & 23.80 & 41.00 & 20.60 & 3.62 & 0.04 & 1.07 & -0.69 & 0.93 \\
\hline $\begin{array}{l}\text { Decrease in Interest rate on } \\
\text { Deposits }\end{array}$ & 5.80 & 13.40 & 31.40 & 29.20 & 20.20 & 3.45 & 0.05 & 1.12 & -0.33 & 0.93 \\
\hline Irregular Communication & 6.60 & 14.40 & 20.00 & 35.80 & 23.20 & 3.55 & 0.05 & 1.18 & -0.55 & 0.93 \\
\hline Decline in Trustworthiness & 6.40 & 9.00 & 15.80 & 52.40 & 16.40 & 3.63 & 0.04 & 1.06 & -0.97 & 0.93 \\
\hline Financially Irregularities & 6.20 & 11.80 & 18.60 & 42.40 & 21.00 & 3.60 & 0.05 & 1.12 & -0.71 & 0.93 \\
\hline Lack of Accuracy & 4.20 & 13.40 & 18.60 & 43.60 & 20.20 & 3.62 & 0.04 & 1.07 & -0.66 & 0.93 \\
\hline Unreliable Online System & 6.60 & 11.60 & 16.00 & 43.00 & 22.80 & 3.64 & 0.05 & 1.14 & -0.77 & 0.93 \\
\hline Delay in Correcting Errors & 6.40 & 12.40 & 12.80 & 51.40 & 17.00 & 3.60 & 0.04 & 1.10 & -0.87 & 0.93 \\
\hline Decline in Service Quality & 7.80 & 9.20 & 16.00 & 41.00 & 26.00 & 3.68 & 0.05 & 1.18 & -0.84 & 0.93 \\
\hline $\begin{array}{l}\text { Failure in Following } \\
\text { 'Citizen's Charter' }\end{array}$ & 3.40 & 13.20 & 38.20 & 29.80 & 15.40 & 3.41 & 0.04 & 1.01 & -0.17 & 0.93 \\
\hline $\begin{array}{ll}\text { Irresponsiveness } \\
\text { Financial Doubts }\end{array}$ & 5.80 & 10.80 & 19.00 & 39.20 & 25.20 & 3.67 & 0.05 & 1.13 & -0.73 & 0.93 \\
\hline Risk of losing the Data & 6.80 & 10.80 & 14.20 & 35.20 & 33.00 & 3.77 & 0.05 & 1.21 & -0.84 & 0.93 \\
\hline
\end{tabular}




\begin{tabular}{|c|c|c|c|c|c|c|c|c|c|c|}
\hline $\begin{array}{l}\text { Frequent Delay in Service } \\
\text { Delivery }\end{array}$ & 4.60 & 10.40 & 16.20 & 43.20 & 25.60 & 3.75 & 0.04 & 1.08 & -0.83 & 0.93 \\
\hline Ignoring the Problems & 5.60 & 12.20 & 13.40 & 37.20 & 31.60 & 3.77 & 0.05 & 1.18 & -0.81 & 0.93 \\
\hline Lack of Competence & 3.80 & 19.40 & 28.20 & 25.80 & 22.80 & 3.44 & 0.05 & 1.15 & -0.17 & 0.93 \\
\hline Rude Behaviour & 6.20 & 11.20 & 14.20 & 33.00 & 35.40 & 3.80 & 0.05 & 1.21 & -0.84 & 0.93 \\
\hline $\begin{array}{l}\text { Neglect of Customer } \\
\text { Feedbacks }\end{array}$ & 4.60 & 17.80 & 19.20 & 32.80 & 25.60 & 3.57 & 0.05 & 1.18 & -0.44 & 0.93 \\
\hline $\begin{array}{l}\text { Competitor's Entry } \\
\text { Immediate locality }\end{array}$ & 5.00 & 30.40 & 28.40 & 23.60 & 12.60 & 3.08 & 0.05 & 1.11 & 0.16 & 0.94 \\
\hline $\begin{array}{l}\text { Displacement of } \\
\text { Customer }\end{array}$ & 5.60 & 16.80 & 24.80 & 33.80 & 19.00 & 3.44 & 0.05 & 1.14 & -0.37 & 0.93 \\
\hline Shifting of Branch & 5.40 & 16.20 & 18.80 & 39.60 & 20.00 & 3.53 & 0.05 & 1.14 & -0.53 & 0.93 \\
\hline
\end{tabular}

SD- Strongly Disagree, D- Disagree, U- Uncertain, A- Agree, SA- Strongly Agree $\mathrm{N}: 500$

\section{Cronbach's Alpha: 0.939}

Table 2 represents reasons of customer relationship dissolution in banking industry. The value of Cronbach's Alpha for all the statements is above 0.900 and overall Cronbach's Alpha is also 0.939, which shows high reliability of the scale. The highest mean score is for the statement 'Rude Behaviour' i.e. 3.80 which makes it most important reason behind dissolving the banking relation with a particular bank. The lowest mean value is for the statement 'Competitor's Entry in Immediate locality' i.e. 3.08, it means respondents are less affected by the entry of competitor in immediate locality and they are less prone to dissolve their banking relation.

Table 3: KMO and Bartlett's Test

\begin{tabular}{|ccc|}
\hline \multicolumn{2}{|c|}{ Kaiser-Meyer-Olkin Measure of Sampling Adequacy. } & .944 \\
Bartlett's Test of Sphericity & Approx. Chi-Square & 5590.764 \\
& $\mathrm{df}$ & 210 \\
& Sig. & .000 \\
\hline
\end{tabular}

Kaiser-Meyer-Olkin (KMO) and Bartlett's test of sphericity was used to test the appropriateness of factor analysis. It is evident from Table 3, the KMO value is .944 which is greater than 0.5 (Malhotra, 2008) and the significance level is 0.000 showing that measures of sampling adequacy are appropriate for factor analysis.

\section{Factor Analysis}

To find out the actual reason of relationship dissolution in banking industry, First of all with the help of extensive literature review 21 factor were identify which may cause dissolution of customer relation by banking customers and then Every respondent was ask to rate the these possible reasons of relationship dissolution. To extract the exact number of reasons responsible for relationship dissolution factor analysis was done using Principal Component Analysis with VERIMAX rotation on these 21 items. Results of Principal Component Analysis are shown in table 4 and table 5 which represents that three reasons emerged after factor analysis of 21 factors 
and factor loading of .5 or greater is enclosed in brackets. Factor 1 has been labelled as Service Quality and Commitment which includes 14 reasons viz. Decline in Trustworthiness; Financially Irregularities; Lack of Accuracy; Unreliable Online System; Delay in Correcting Errors; Decline in Service Quality; Failure in Following 'Citizen's Charter'; Irresponsiveness towards Financial Doubts; Risk of losing the Data; Frequent Delay in Service Delivery; Ignoring the Problems; Lack of Knowledge/Competence; Rude Behaviour; and Neglect of Customer Feedbacks. Factor 2 has been labelled as Price and Communication which includes Increase in Fees/Penalties; Increase in Interest Rate on Loan; Decrease in Interest Rate on Deposits; and Irregular Communication. Last factor labelled Involuntary Dissolution includes Competitor's Entry in Immediate locality; Displacement of the Customer; and Shifting of Branch.

Table 4: Varimax Rotated Factor Matrix

\begin{tabular}{|c|c|c|c|}
\hline Variables & Factor 1 & Factor 2 & Factor 3 \\
\hline 1.Increase in Fees/Penalties & .316 & {$[.724]$} & .061 \\
\hline 2. Increase in Interest Rate on Loan & .225 & {$[.780]$} & .254 \\
\hline 3. Decrease in Interest Rate on Deposits & .148 & {$[.682]$} & .261 \\
\hline 4. Irregular Communication & .298 & {$[.705]$} & .011 \\
\hline 5. Decline in Trustworthiness & {$[.743]$} & .303 & -.100 \\
\hline 6. Financially Irregularities & [.669] & .326 & .015 \\
\hline 7. Lack of Accuracy & {$[.640]$} & .260 & .221 \\
\hline 8. Unreliable Online System & {$[.685]$} & .240 & .310 \\
\hline 9. Delay in Correcting Errors & {$[.734]$} & .253 & .133 \\
\hline 10. Decline in Service Quality & {$[.741]$} & .068 & .325 \\
\hline 11. Failure in Following 'Citizen's Charter' & {$[.618]$} & .148 & .276 \\
\hline 12. Irresponsiveness towards Financial Doubts & {$[.701]$} & .206 & .261 \\
\hline 13. Risk of losing the Data & {$[.673]$} & .294 & .191 \\
\hline 14. Frequent Delay in Service Delivery & {$[.703]$} & .233 & .224 \\
\hline 15. Ignoring the Problems & {$[.701]$} & .157 & .190 \\
\hline 16. Lack of Competence & {$[.595]$} & .244 & .250 \\
\hline 17. Rude Behaviour & {$[.676]$} & .195 & .257 \\
\hline 18. Neglect of Customer Feedbacks & {$[.613]$} & .160 & .220 \\
\hline 19. Competitor's Entry in Immediate locality & .116 & .065 & {$[.708]$} \\
\hline 20. Displacement of the Customer & .358 & .174 & {$[.663]$} \\
\hline
\end{tabular}




\begin{tabular}{lccc} 
21. Shifting of Branch & .339 & .263 & {$[.646]$} \\
\hline Explained Variance per factor & $\mathbf{4 5 . 8 6}$ & $\mathbf{6 . 5 5}$ & $\mathbf{5 . 3 9}$ \\
Cumulative & $\mathbf{4 5 . 8 6}$ & $\mathbf{5 2 . 4 1}$ & $\mathbf{5 7 . 8 0}$ \\
\hline
\end{tabular}

No. of cases 500

[ ] indicates the highest loading in each row

Table 5: Emerging Factors (Reasons) Causing Dissolution of Banking Relationship

\section{Factor 1 Service Quality and Commitment}

- Decline in Trustworthiness

- Financially Irregularities

- Lack of Accuracy

- Unreliable Online System

- Delay in Correcting Errors

- Decline in Service Quality

- Failure in Following 'Citizen's Charter'

- Irresponsiveness towards Financial Doubts

- Risk of losing the Data

- Frequent Delay in Service Delivery

- Ignoring the Problems

- Lack of Competence

- Rude Behaviour

- Neglect of Customer Feedbacks

Factor 2 Price and Communication

- Increase in Fees/Penalties

- Increase in Interest Rate on Loan

- Decrease in Interest Rate on Deposits

- Irregular Communication

Factor 3 Involuntary Dissolution

- Competitor's Entry in Immediate locality

- Displacement of the Customer

- Shifting of Branch

\section{Conclusion and Recommendations}

The study found that though there are various reasons why a customer dissolves its relationship with a particular bank but broadly these can be grouped into three categories includes Service Quality and Commitment; Price and Communication; and Involuntary Dissolution. Out of these three reasons, Service Quality and Commitment seems to be most important reason of dissolving a banking relationship as this reason alone contributes 45.86 percent in dissolution decision. 
Then it is followed by Price and Communication and Involuntary Dissolution is the least important reason behind dissolving a banking relationship. It is suggested that banks should focus more on improving the service quality and bring the sense of commitment among their employees. Banks must put their sincere efforts in improving the their trustworthiness, citizen's charter must be followed religiously, any kind of delay in service delivery should be avoided, competence level of the staff must be developed through training and development activities, employees should behave in polite manner. On other hand bank should maintain competitive rate of interest and various fees \& charges levied on the bank accounts to retain their customers; and there should be a regular communication with the customers. Involuntary Dissolution is the reason where banks have least opportunity to reduce it.

\section{References}

[1] Athanassopoulos, A., Gounaris, S. and Stathakopoulos, V., Behavioural responses to customer satisfaction: an empirical study, European Journal of Marketing, Vol. 35 Nos. (5/6), 2001, 687707.

[2] Bansal, H.S., Irving, P.G. and Taylor, S.F., A three-component model of customer commitment to service providers, Journal of the Academy of Marketing Science, Vol. 32 No. 3, 2004, 234-250.

[3] Beckett, A., Hewer, P. and Howcraft, B., An exposition of consumer behaviour in the financial services industry, International Journal of Bank Marketing, Vol. 18 No. 1, 2000, 15-26.

[4] Bejou, D. and Palmer, A., Service failure and loyalty: an exploratory empirical study of airline customers, Journal of Services Marketing, Vol. 12 No. 1, 1998, 7-22.

[5] Bolton, Ruth N., A Dynamic Model of the Duration of the Customer's Relationship with a Continuous Service Provider: The Role of Satisfaction, Marketing Science, 17 (1), 1998, 45-65.

[6] Chakravarty, S., Feinberg, R. and Rhee, E.Y., Relationships and individuals bank switching behavior, Journal of Economic Psychology, Vol. 25 No. 4, 2004, 507-527.

[7] Clemes, M., Mollenkoph, D. and Burn, D., An investigation of marketing problems across service typologies, Journal of Services Marketing, Vol. 14 No. 7, 2000, 573-594.

[8] Clemes, M.D., Gan, C. and Zheng, L.Y., Customer switching behaviour in the New Zealand banking industry, Banks and Bank Systems, Vol. 2 No. 4, 2007, 50-65.

[9] Friedman, M.L. and Smith, L.J., Consumer evaluation processes in a service setting, Journal of Services Marketing, Vol. 7 No. 2, 1993, 47-61.

[10] Ganesh, J., Arnold, M.J. and Reynolds, K.E., Understanding the customer base of service providers: an examination of the differences between switchers and stayers, Journal of Marketing, Vol. 64 No. 3, 2000, 65-87.

[11] Gerrard, P., J., \& Cunningham, J. B., Consumer switching behavior in the Asian banking market, Journal of Services Marketing, 18, 2004, 215-223.

[12] Gilliland, D.I. and Bello, D.C., Two sides to attitudinal commitment: the effect of calculative and loyalty commitment on enforcement mechanisms in distribution channels, Journal of the Academy of Marketing Science, Vol. 30 No. 1, 2002, 24-43.

[13] Gronroos, C., Relationship approach to marketing in service contexts: the marketing and organizational behavior interface, Journal of Business Research, Vol. 20, 1990, 3-11.

[14] Halinen, A. and Salmi, A., Managing the informal side of business interaction: personal contacts in the critical phases of business relationships, paper presented at the 17th IMP Conference, Oslo, 1990.

[15] Kaur, G., Sharma, R.D. and Mahajan, N., Exploring customer switching intentions through relationship marketing paradigm, International Journal of Bank Marketing, Vol. 30 No. 4, 2012, 280-302.

[16] Keaveney, S. M., Customer switching behavior in service industries: An exploratory study, Journal of Marketing, Vol. 59 No. 2, 1995, 71-82. 
[17] Keaveney, S.M., \& Parthasarathy, M., Customer switching behavior in online services: An exploratory study of the role of selected attitudinal, behavioral, and demographic factors, Journal of the Academy of Marketing Science, 29, 2001, 374-90.

[18] Klein, E., Global Banking Issues, Nova Science Publishers, New York, NY, 2005

[19] Kumar, A. and Shashi, C.M., Confirmatory analysis of aggregate hierarchical market structures: inferences from brand switching behavior, Journal of Marketing Research, Vol. 26 No. 4, 1989, 444-453.

[20] Kura K.M., Mat N.K.N, Gorondutse A.H., Magaji A.M. \& Yusuf A., Modeling the Antecedents of Customer Switching Behaviour in Nigerian Banking Industry, American Journal of Economics, June 2012 (Special Issue), 29-36.

[21] Levesque, T.J. and McDougall, G., Determinants of customer satisfaction in retail banking, International Journal of Bank Marketing, Vol. 14 No. 7, 1996, 12-20.

[22] Mahapatra S.N., An empirical analysis of cause of consumer dissatisfaction and the reasons why consumers Enduring Dissatisfaction, Serbian Journal of Management, vol.9 No. 1, 2014, 71-89

[23] Maiyaki, A. A., \& Mokhtar, S. S. M., Determinants of customer behavioural intention in Nigerian retail banks, Interdisciplinary Journal of Research in Business 1(10), 2011, $42-48$.

[24] Malhotra, N.K., Marketing Research: An Applied Orientation, 5th Ed., Prentice Hall of India Private Ltd., New Delhi, 2008.

[25] Mavri, M. and Ioannou, G., Customer switching behaviour in Greek banking services using survival analysis, Managerial Finance, Vol. 34 No. 3, 2008, 186-197.

[26] McAlister, L. and Pessemier, E.A., Variety seeking behaviour: an interdisciplinary review, Journal of Consumer Research, Vol. 9 No. 3, 1982, 311-322.

[27] Mittal, B. and Lassar, W.M., Why do customers switch? The dynamics of satisfaction versus loyalty, The Journal of Services Marketing, Vol. 12 No. 3, 1998, 177-194.

[28] Moutinho, L., \& Smith, A., Modeling bank customer satisfaction through mediation of attitudes towards human and automated banking, International Journal of Bank Marketing, Vol.18 No.3, 2000, 124-134.

[29] Reid, D.A., Bolman-Pullins, E., Plank, R.E. and Buehrer, R.E., Measuring buyers' perceptions of conflict in business-to-business sales interactions, Journal of Business \& Industrial Marketing, Vol. 19 No. 4, 2004, 236-49.

[30] Rust, R.T. and Zahorik, A.J., Customer satisfaction, customer retention and market share, Journal of Retailing, Vol. 69 No. 2, 1993, 193-215.

[31] Sajtos, L. and Kreis, H., Diagnosing the impact of patronage concentration and cross-buying in retail banking, Journal of Business Market Management, Vol. 4 No. 39, 2010. 151-165.

[32] Sathish, M., Kumar, K.S., Naveen, K.J. and Jeevanantham, V., A study on consumer switching behaviour in cellular service provider: a study with reference to Chennai, Far East Journal of Psychology and Business, Vol. 2 No. 2, 2011, 71-81.

[33] Stewart, K., An exploration of customer exit in retail banking, International Journal of Bank Marketing, Vol. 16 No. 1, 1998, 6-14.

[34] Vyas, V. and Raitani S., Drivers of customers' switching behaviour in Indian banking industry, International Journal of Bank Marketing, Vol.32 No.4, 2014, 321-342

*Corresponding author.

E-mail address: pkkalria@gmail.com 